\title{
Miten varmistaa osaaminen työelämän muutoksessa?
}

\author{
Arja Haapakorpi
}

Alustus Tampereen yliopiston, sosiaali- ja terveysministeriön ja työ- ja elinkeinoministeriön ILO:n 100-vuotisen taipaleen kunniaksi järjestämässä seminaarissa "Osaaminen ja johtajuus muuttuvassa työelämässä", 9.5.2019, Tampereen yliopisto

Osaamisen rapautuminen työelämän muutosten ja digitaalisten teknologioiden käyttöönoton myötä on vakiintunut huolenaiheeksi julkisessa keskustelussa. Näkökulma on usein ylhäältä alaspäin katsova ja siitä välittyy näkemys kansalaisista ja työvoimasta toimenpiteiden kohteena. Uusia käsitteitä on kehitelty tämän huoli-keskustelun sytykkeiksi, ja osa näistä käsitteistä, kuten niin sanottu alaisosaaminen, on luonteeltaan enemmänkin normatiiviseen hallintaan perustuvaa kuin varsinaisesti kompetenssien kehittämiseen paneutuvaa. Vakavaan keskusteluun tarvitaan kuitenkin arvostava ihmiskuva, yhteiskunnallista näkemystä ja työn muutosten analyyttistä tarkastelua. Osaamisen kehittämistä ei voida kohdentaa vain työelämässä tarvittaviksi taidoiksi ja tiedoiksi, sillä ihminen on yhteiskunnallinen, sosiaalinen ja yksilöllinen toimija, jonka oppiminen tapahtuu näiden roolien ja toimijuuden kautta. Pakkojen sijaan oppimisen mahdollisuuksien luominen erilaisissa yhteiskunnallisissa tiloissa rakentaa kestävää osaamista. Oikotietä kestävään osaamiseen ei siis voi luoda uusien taitojen täsmäkoulutuksilla, vaikka niilläkin on oma sijansa tilannekohtaisissa muutoksissa. Osaaminen työelämässä kehittyy useilla inhimillisillä ja yhteis- kunnallisilla kentillä, joilla on systemaattisesti luotuja tai tahattomia oppimisen tiloja.

Koulutusjärjestelmä on tietysti kulmakivi nuorten ja aikuistenkin oppimiselle, mutta työelämässä ja kansalaisena toimiminen on toinen puoli kestävästä oppimisesta ja osaamisesta. Työelämä ja ammatit muuttuvat, mutta hyvä peruskoulutus luo pohjan niin perustaidoille kuin oman elämän käsikirjoittajuudelle. Kansalaisena toimiminen antaa oppimisen mahdollisuuksia yhteiskunnallisessa vaikuttamisessa ja oman roolin ja aseman ottamisessa yhteiskunnassa. Ihminen omia valintojaan tekevänä tietoisena kansalaisena oppii vastuun ottamisen ja vaikutusvallan kautta myös tärkeää työelämässä tarvittavaa osaamista ja roolin ottoa. Työelämä tarjoaa parhaimmillaan oppimisen tiloja vaihteleviin ja uusiin tehtäviin ja rooleihin. Kaikki kolme yhteiskunnallista aluetta - koulutus, kansalaisena toimiminen ja työelämä - ovat merkityksellisiä oppimisen tilojen tarjoamisessa ja osaamisen kehittymisessä.

\section{Koulutusjärjestelmän toimivuus edellyttää resursseja}

Suomalaiselle, kuten myös laajemmin pohjoismaiselle koulutusjärjestelmälle on ominaista opiskelupolkujen joustavuus ja koulutuksen umpiperien puuttuminen: toisen asteen ammatillisestakin koulutuksesta voidaan jatkaa korkeakoulutasolla, ja järjestelmä sallii myös siir- 
tymät toiseen suuntaan eli korkeakouluista toisen asteen ammatillisiin oppilaitoksiin. Ammatillisen koulutuksen järjestelmää on kehitetty useiden vuosikymmenten ajan nykyiseen muotoonsa (Virolainen \& Stenström 2015), ja sen joustavuus mukautuu erilaisten opiskelijaryhmien ja työnantajien tarpeisiin, sillä opiskelu perustuu henkilökohtaistamiselle ja järjestelmässä on vaihtoehtoisia väyliä tutkinnon suorittamiseen.

Erilaisissa elämäntilanteissa olevat ja erityistä tukea tarvitsevat opiskelijat on otettu huomioon koulutusjärjestelmän rakentamisessa. Koulutuksen ja opiskelun rakenteet edellyttävät riittävästi opetushenkilökuntaa, jotta tavoitteet voidaan toteuttaa. Esimerkiksi toisen asteen ammatillisen koulutuksen henkilökohtaistaminen perustuu pitkäjänteiseen opiskelijan ohjaukseen ja tukemiseen, koska opiskelijoiden tarpeet ja lähtökohdat ovat vaihtelevia ja tilanteet muuttuvat myös opintojen edetessä. Lisäksi ammatilliseen koulutukseen kytkeytyvä työelämässä oppiminen erilaisissa muodoissaan ei toteudu tasapuolisesti, sillä työnantajien tarjoamat tehtävät ja ohjaus vaihtelevat oppilaitosten laatutyöstä huolimatta (Haapakorpi 2018). Ammatillisen koulutuksen institutionaalinen eli valvova ja korjaava rooli on siis keskeinen myös koulutuksen laadun seurannassa ja laatuongelmien ratkaisemisessa. Erityisryhmien tukeminen oppilaitoksissa ei valitettavasti ulotu työelämään: vaikka koulutuksessa tarjotaan erityistukea sitä tarvitseville opiskelijoille, osatyökykyiset ja vammaiset kohtaavat syrjintää niin työttömyyden, työllistymisvaikeuksien kuin heikkojen työsopimusehtojenkin muodossa (Vesala, Klem \& Ahlstén 2015).

Koulutus ei ole vain työelämää varten. Yhteiskunnallista vastuuta kantavana instituutiona koulutuksen tehtävänä on laajempien yhteiskunnallisten arvojen ja parlamentaarisesti sovittujen tavoitteiden toteuttaminen. Koulutuksen tavoitteena on tukea myös nuorten kehittymistä kansalaisina, jotta heidän mahdollisuutensa toimia yhteiskunnassa toteutuvat. Institutionaalisessa koulutuksessa rakennetaan yhteiskunnassa ja omassa elämässä tarvittavia orientaatioita tietojen ja taitojen oppimisen lisäksi. Aktiivinen kansalaisuus ja valintojen tekeminen omista lähtökohdista sekä vastuunoton ja vaikutusvallan haltuunotto ovat toimijan orientaatio, jolla tiedot ja taidot otetaan käyttöön (Eteläpelto, Heiskanen \& Collin 2011; Gordon 2008).

Koulutusjärjestelmä on rakennettu hierarkkisesti koulutuksen ja koulutusammatin vaativuuden mukaan. Alun perin järjestelmän perustana on ollut ruumiillisen ja henkisen työn erottaminen ja tämän erottelun luoma polkuriippuvuus on havaittavissa nykyjärjestelmässä. Tämä hierarkkisuus ei välttämättä luo joustavinta tapaa vastata yhteiskunnan ja työelämän muutoksiin, vaikka järjestelmän edellyttämät rakenteet on hallittavuuden näkökulmasta rakennettu loogisesti. Muun muassa teknologiset, työnorganisaation liittyvät muutokset voivat sekoittaa tätä järjestystä, sillä ammattien muutoksessa samaan työnkuvaan ja -rooliin voidaan yhdistää keskiasteen ja korkea-asteen koulutusta vaativia tehtäviä teknologiavälitteisissä työympäristöissä (Autor 2013; Haapakorpi 2017). Toisen asteen koulutuksessa on ollut mahdollista sisällyttää opintoihin korkea-asteen opintoja, mutta tätä mahdollisuutta on hyödynnetty varsin vähän. Odotettavissa oleva ammattien muutos haastaa järjestelmän hierarkiarakennetta erityisesti koulutuksen järjestämisen käytännöissä.

Aikuiskoulutuksen kehittämistä on heikentänyt sen epämääräinen asema usean hallinnonalan yhteisvastuulla tai jaetulla vastuulla. Vuonna 2018 voimaan astuneessa ammatillisen koulutuksen reformissa vastuuta siirrettiin opetus- ja kulttuuriministeriölle, mutta työhallinnolla on yhä rooli työvoimakoulutuksen hallinnoinnissa pitkän perinteen saattelemana.

Koulutusjärjestelmän kehittäminen on pitkäjänteistä ja aikaa vaativaa, mutta sen toimivuus voi heikentyä lyhyessäkin ajassa. Edellisen hallituksen toteuttamat resurssien karsimiset nostivat ongelmat esille erityisesti ammatillisessa koulutuksessa. Teoreettista 
opetusta siirrettiin työpaikoille, joilla ei ole ollut edellytyksiä täyttää näitä odotuksia, ja oppilaitosten resursseja tehtävänsä täyttämiseksi heikennettiin. Uusi hallitus on luvannut korjata tilannetta.

\section{Työn organisointi, työelämän suhteet ja ihmiskuva oppimistilojen rakentajana}

Työelämälähtöinen oppiminen nostettiin työpolitiikan asialistan kärkeen muutama vuosikymmen sitten, mikä liittyi 1980-luvulta lähtien alkaneeseen käänteeseen, jossa työelämäsuhteita ja työn tekemisen rooleja asemoitiin uudelleen tutkimusperustaisesti (Alasoini \& Ramstadt 2007). Työpolitiikassa kehitettiin pohjoismaisen mallin mukaista työnantajan ja työntekijän välistä yhteistoimintaa työn tuottavuuden ja laadun nostamiseksi sekä korkean ammattitaidon kehittämiseksi. Työn organisointia ja henkilöpolitiikkaa uudistettiin: vastuun ja vaikutusvallan delegoinnin ajateltiin hyödyttävän sekä työnantajia että työntekijöitä (Julkunen 2008).

Työn vaativuus on noussut uusien teknologioiden käyttöönoton, tuottavuutta tavoittelevan työn organisoinnin uudistusten sekä koulutustason nousun myötä, ja lähes jokaiseen tehtävään on määritelty koulutusvaatimukset. Teknologioiden digitaalistumista on tapahtunut jo pitkän aikaa erilaisissa, osin huomaamattomissakin muodoissa: älypuhelin on otettu käyttöön niin vanhusten kotihoidossa kuin varastotyössäkin. Siten emme ole uuden ja odottamattoman edessä, vaan jo keskellä uusien teknologioiden käyttöönoton prosesseja. Joillakin aloilla, kuten pankkipalveluissa ja vähittäiskaupassa, yksinkertaista työtä korvataan teknologialla, mutta yleisin muutos on teknologiavälitteisten työtehtävien lisääntyminen ja tehtävien uudelleen organisointi (Autor 2013).

Työpaikalla oppimisen tilojen tarjoaminen on monen tekijän summa (Kelley 1990), ja henkilöstöstrategiat painottavat vaihtelevasti uusien tehtävien ja roolien oppimisen merki- tystä. Uusien teknologiavälitteisten tehtävien ja työn uudelleen organisoinnin oppimista voi tapahtua työnantajan järjestämän koulutuksen, mutta myös arjessa tapahtuvan oppimisen kautta. Uuden teknologian käyttöönotossa strategiat vaihtelevat. Osa pitäytyy passiivisessa roolissa HR-kustannusten kohoamisen välttämiseksi (Wall, Jackson \& Davids 1992). Valistuneet työnantajat taas kehittävät systemaattisesti koulutusta ja sellaisia työn organisoinnin muotoja, joilla edistetään henkilöstön osaamista (Snell, Lepak, Dean \& Youndt 2000; Bayo-Moriones, Bello-Pintado \& Merino-Díazde-Cerio 2010). Työntekijöiden työnkuvan ja osaamisen kehittymisen myötä tuotantovarmuus parantuu ongelmanratkaisukyvyn myötä (Haapakorpi 2017). Työnkuvan monipuolistaminen ja työroolien uudistaminen ovat keinoja motivoida oppimista. Esimerkiksi tuotannon työntekijöiden omaksuma asiantuntijarooli eli suora asiakaskontakti ongelmatilanteissa kehittää refleksiivistä otetta työn tekemiseen. Taustalla näissä osaamista kehittävissä työn organisoinnin menetelmissä on ihmiskuva, jossa ihminen nähdään vastuullisena ja aktiivisena toimijana, mutta yhtä usein kyse on kannattavuudesta: vastuun ja vaikutusvallan delegoiminen antaa oppimisen tiloja ja työnantajalle osaavan työntekijän (ks. Julkunen 2008).

Uusien työn organisoinnin keinojen kehittäminen ei kuitenkaan ole ristiriidatonta. Ensinnäkin kaikki työntekijät eivät halua laajentaa työnkuvaansa tai rooliaan yli sovitun. Toiseksi työpaikat ovat hierarkkisia ja joidenkin ammattitehtävien vaativuuden nostaminen voidaan kokea muissa työntekijäryhmissä uhkana. Kolmanneksi työn vaativuuden nostaminen nostaa esiin kysymyksen palkitsemisesta, sillä vaativissa tehtävissä palkkaus on yleensä korkeampi kuin vähemmän vaativissa. Neljänneksi useat tutkimukset raportoivat vastuun kohtuutonta kasvua suhteessa työhön liittyviin vaikutusmahdollisuuksiin sekä vastuuseen liittyviä terveysriskejä. (Julkunen 2008.) Voidaan myös pohtia kokopäiväisen ja jatkuvan työsuhteen ulkopuolelle jäävien ti- 
lannetta oppimisen näkökulmasta, sillä tilapäistyövoimaan tuskin panostetaan samalla tavoin kuin vakituiseen työvoimaan.

Päätän katsauksen kuitenkin myönteisissä merkeissä eli tarkastelen suomalaisen työelämän oppimisen ja kehittymisen mahdollisuuksia kansainvälisessä tilastovertailussa. Eurooppalaiset tilastot kertovat Pohjoismaiden erityisyydestä oppimisen ja osaamisen tilojen luomisessa. Oheisten tilastojen (taulukot 1-3) lähde on Eurofoundin (2016) European Working Conditions Survey. Vaikka näihinkin kansainvälisiin vertailuihin sisältyy epävarmuustekijöitä, voidaan niitä pitää kuitenkin suuntaa-antavina.

Pohjoismaiden työpaikoilla näyttää olevan näiden tilastojen mukaan verrattain hyvin tarjolla uusien asioiden oppimista sekä mahdollisuuksia soveltaa omia ideoita. Sen sijaan vastaajien näkemykset mahdollisuuksista osallistua työn kehittämiseen työorganisaatiossa tai työyksikössä hajautuvat selvästi enemmän, mikä voi liittyä myös kysymyksen mahdolliseen monitulkintaisuuteen.

Taulukko 1. Sisältääkö työsi uusien asioiden oppimista? Kyllä-vastausten osuus, \%

\begin{tabular}{|c|c|}
\hline Maa & $\begin{array}{l}\text { Sisältääkö työ uusien asioiden } \\
\text { oppimista? Kyllä-vastaukset, \% }\end{array}$ \\
\hline Suomi, Norja, Tanska, Ruotsi & $89-91$ \\
\hline Ranska, Belgia, UK, Irlanti, Alankomaat, Slovenia, Viro & $77-84$ \\
\hline $\begin{array}{l}\text { Saksa, Espanja, Puola, Tsekki, Itävalta, Sveitsi, Bulgaria, Slovakia, } \\
\text { Romania, Serbia, Kroatia }\end{array}$ & $60-73$ \\
\hline Italia, Portugali, Kreikka, Albania, Unkari, Liettua, Latvia & $51-60$ \\
\hline
\end{tabular}

Taulukko 2. Onko sinulla mahdollisuus osallistua työn organisoinnin tai työprosessien kehittämiseen työorganisaatiossasi tai työyksikössäsi? Vastausten "Aina tai useimmiten" ja "Ei koskaan tai harvoin" osuus, \%

\begin{tabular}{|l|c|c|l|c|c|}
\hline Maa & $\begin{array}{c}\text { Aina tai } \\
\text { useimmiten }\end{array}$ & $\begin{array}{c}\text { Ei koskaan } \\
\text { tai harvoin }\end{array}$ & \multicolumn{1}{|c|}{ Maa } & $\begin{array}{c}\text { Aina tai } \\
\text { useimmiten }\end{array}$ & $\begin{array}{c}\text { Ei koskaan } \\
\text { tai harvoin }\end{array}$ \\
\hline Norja & 56 & 13 & Suomi & 51 & 27 \\
\hline Tanska & 57 & 19 & UK & 51 & 26 \\
\hline Ranska & 61 & 22 & Ruotsi & 45 & 25 \\
\hline Espanja & 57 & 26 & Italia & 50 & 31 \\
\hline Irlanti & 59 & 23 & Saksa & 37 & 41 \\
\hline
\end{tabular}

Taulukko 3. Pystytkö soveltamaan omia ideoitasi työssäsi? Vastausten "Aina tai useimmiten" ja "Ei koskaan tai harvoin" osuus, \%

\begin{tabular}{|l|c|c|l|c|c|}
\hline Maa & $\begin{array}{c}\text { Aina tai } \\
\text { useimmiten }\end{array}$ & $\begin{array}{c}\text { Ei koskaan } \\
\text { tai harvoin }\end{array}$ & \multicolumn{1}{|c|}{$\begin{array}{c}\text { Maa } \\
\text { Aina tai } \\
\text { tai harvoimmiten }\end{array}$} & 63 \\
\hline Suomi & 73 & 7 & Ranska & 69 & 16 \\
\hline Tanska & 69 & 8 & Espanja & 66 & 53 \\
\hline Ruotsi & 66 & 9 & Belgia & 44 & 34 \\
\hline Norja & 64 & 10 & Italia & 41 & 33 \\
\hline Irlanti & 68 & 15 & Saksa & Puola & 32 \\
\hline UK & 62 & 14 & &
\end{tabular}




\section{Lopuksi}

Osaamisen varmistaminen työelämän muutoksissa on monitahoinen tehtävä, sillä työelämän osaamista ei voi irrottaa yhteiskunnallisesta ja kansalaisuuteen sekä ihmisyyteen perustuvasta toiminnasta ja tiedon tulkinnasta sekä soveltamisesta. Osaaminen varmistetaan parhaiten pitkäjänteisellä ja tasapuolisella koulutus- ja yhteiskuntapolitiikan kehittämisellä, työelämän toimintakulttuurin edistämisellä ja kansalaisyhteiskunnan edellytysten turvaamisella.

\section{Kirjoittaja}

Arja Haapakorpi, VTT, dos., yliopistotutkija, Tampereen yliopisto, sähköposti: arja.haapakorpi@tuni.fi

\section{Kirjallisuus}

Alasoini, T. \& Ramstad, E. (2007) Johdanto. Teoksessa E. Ramstad \& T. Alasoini (toim.) Työelämän tutkimusavusteinen kehittäminen Suomessa. Lähestymistapoja, menetelmiä, kokemuksia, tulevaisuuden haasteita. Helsinki: TYKES, 3-14.

Autor, D. H. (2013) The 'task approach' to labor markets: An overview: National Bureau of Economic Research, Inc, NBER Working Papers: 18711. [online]. <URL:https://ideas.repec.org/p/nbr/nberwo/18711.html>. Luettu 10.2.2019

Bayo-Moriones, A., Bello-Pintado, A. \& Merino-Díazde-Cerio, J. (2010) The effects of integrated manufacturing on job characteristics. New Technology, Work and Employment 25 (1), 63-79.

Eteläpelto, A., Heiskanen, T. \& Collin, K. (2011) Vallan ja toimijuuden monisäikeisyys ja toimijuus. Teoksessa A. Eteläpelto, T. Heiskanen \& K. Collin (toim.) Valta ja toimijuus aikuiskasvatuksessa. Aikuiskasvatuksen 49. vuosikirja. Helsinki: Kansanvalistusseura, 9-30.

Gordon, T. (2008) Toimijuuden käsitteen dilemmoja. Teoksessa A. Meurman-Solin \& I. Pyysiäinen (toim.) Ihmistieteet tänään. Helsinki: Gaudeamus, 114-130.

Haapakorpi, A. (2017) Työnkuvien muutokset metallialan teknologiavälitteisessä ympäristössä: katkoksellisuus ja asteittaisuus. Työelämän tutkimus 15 (1), 3-22.

Haapakorpi, A. (2018) Oppisopimuskoulutuksen toteutuminen työpaikoilla - lähestymistapana institutionaalinen teoria. Hallinnon tutkimus. 36 (4), 226-241.

Julkunen, R. (2008) Uuden työn paradoksit: keskusteluja 2000-luvun työprosess(e)ista. Tampere: Vastapaino.

Kelley, M. (1990) New process technology, job design, and work organization: A contingency model. American Sociological Review 55 (2), 191208.

Snell, S., Lepak, D., Dean, J \& Youndt, M. A. (2000) Selection and training for integrated manufacturing: The moderating effects of job characteristics. Journal of Management Studies 37 (3), 445-466.

Wall, T., Jackson, P. \& Davids, K. (1992) Operator work design and robotics system performance: A serendipitous field study. Journal of Applied Psychology 77 (3), 353-362.

Vesala, H. Klem, S. \& Ahlstén, M. (2015). Kehitysvammaisten ihmisten työllisyystilanne 20132014. Helsinki: Kehitysvammaliiton selvityksiä 9.

Virolainen, M. \& Stenstöm, M.-L. (2015) Recent Finnish VET reforms and innovations: Tackling the current challenges. Nord-VET - The future of VET in the Nordic Countries. Roskilde: Department of Psychology \& Educational Studies Roskilde University. 